\title{
Effects of habitat complexity on the structure of macrobenthic association in a Spartina alterniflora marsh
}

\author{
Maurea Nicoletti FLYNN*; Airton Santo TARARAM \& Yoko WAKABARA \\ Instituto Occanográfico da Universidade de São Paulo \\ (Caixa Postal 66149, 05389-970 São Paulo, SP, Brasil)
}

- Abstract: The structure and scasonal variability of macrobenthic associations in four different patches on a Spartina alterniflora bed at Arrozal Point, Cananéia, São Paulo State are described and compared. In the local intertidal marsh, densities of S. alierniflora plants appear in sparsely or densely arranged patches, both in tall and short forms. The infaunal polychactes Capitella capitata, Isolda pulchella, Nereis oligohalina and Laconereis acuta accounted for $44.0 \%$ of the total individuals while epifaunal forms such as Heleobia australis, Littorina angulifera, Tholozodium rhombofrontalis and Sphaeromopsis mourei were the second most abundant components with $39.5 \%$. Classification analyses of sampling time in the same sampling patch indicated that species groups were formed basically by spatial similarity and peak densilies of macrofauna and secondarily by temporal patterns. Temporal variations were evident with higher number of species in colder months (winter and spring). Species diversity and evenness did not show clear seasonal patterns, although they were significantly different in sampling patches and time. Heleobia australis, Littorina angulifera and Anomalocardia brasiliensis were dominant in tall sparse $S$. altemiflora with density peaks occurring in winter/spring periods. Tholozoditum rhombofrontalis and Sphaeromopsis mourei were dominant in short sparse S. altemiflora with density peaks in summer. In tall, densely distributed $S$. alterniflora plants the higher densities occurred in winter and the dominant species were Nereis oligohalina, Isolda pulchella and Capitella capitata. The species $H$. australis, L. angulifera and $A$. hrasiliensis predominated in the short $S$. allemiflora plants densely distributed, with faunistic peaks recorded in spring. The results suggest that differences in form and aggregation of $S$. alterniflora impart changes in the structure of macrobenthic fauna associated to this vegetation.

- Resumo: A estrutura e variação temporal de associaçōes macrobentônicas de marismas de Sparina alterniflora, estruturalmente diferentes com relação à forma (baixa ou alta) e ao grau de agregação (esparsa ou agregada), foram descritas e comparadas, na Ponta do Arrozal, região de Cananéia, costa sul do Estado de São Paulo. Representantes da infauna como os poliquetos Capitella capitata, Isolda pulchella, Nereis oligohalina e Laeonereis acuta perfizeram 44,0\% da fauna coletada, enquanto que formas cpifaunais como Heleobia australis, Littorina angulifera, Tholozodium rhombofrontalis e Sphaeromopsis mourei atingiram 39,5\%. Análises classificatórias dos períodos de amostragem indicaram que os agrupamentos de espécies foram formados basicamente pela similaridade espacial c picos de densidade da macrofauna seguidos pelos padrōes de variaçāo temporal. Os maiores valores de diversidade ocorreram no inverno e primavera. Os índices de diversidade c equitatividade, embora significativamente diferentes entre locais de amostra e tempo, não mostraram um padrão sazonal muito claro. Heleobia australis, Littorina angulifera e Anomalocardia brasiliensis foram dominantes entre as plantas altas de $S$. altemiflora, esparsamente distribuídas, com picos de densidade faunística ocorrendo nos períodos de inverno e primavera. Entre as plantas baixas esparsamente distribuídas as espécies dominantes foram Tholozodium rhombofrontalis e Sphacromopsis mourei, com maior densidade no verão. Nas plantas altas $\mathrm{e}$ agregadas as maiores densidades ocorreram no inverno e as espécies dominantes foram Nereis oligohalina, Isolda pulchella e Capitella capitata. As espécics $H$. australis, $L$. angulifera $\mathrm{c} A$. brasiliensis dominaram nas marismas baixas e agregadas, apresentando os maiores valores de densidade na primavera. Os resultados sugerem que diferenças na forma e agregação de $S$. alterniflora provocam mudanças na estrutura da fauna macrobentônica associada a esta vegetação.

- Descriptors: Habitat complexity, macrobenthic association, Spartina altemiflora marsh, Southern coast of São Paulo State, Brazil.

- Descritores: Complexidade de habilat, Asssociaçōes macrobentônicas, marisma de Spartina allemiflora, Costa sul do Estado de Sáo Paulo, Brasil.

(*) Bolsista de pós-doutorado do $\mathrm{CNPq}$

Contr. no. 794 do Inst. oceanogr. da Usp. 


\section{Introduction}

It has been amply demonstrated that structural elements such as plant cover strongly influence macrobenthic associations and can lead to remarkable faunistic differences between vegetated and bare sites or between habitats with different types of vegetation. Evidence has been provided by studies comparing sites with different species of seagrass (Lewis, 1984; Virnstein \& Howard, 1987); vcgetated and unvegetated habitats (Lewis \& Stoner, 1983; Lana \& Guiss, 1991) and sites with seagrass and macroalgae (Schneider \& Mann, 1991). The majority of works on grassy bottoms deals with seagrass habitats. Although intertidal marshes and subtidal seagrass meadows are believed to exhibit similarities in their functional and structural roles (Orth et al., 1984), contradictory patterns of macrobenthic organization have been described for those environments, fully justifying more studies of the salt marsh habitat.

Changes in the density or size of artificial plants lead to varied responses from macrobenthic communities (Gunnil, 1983; Edgar, 1990). These alterations are normally attributed to the effect of macrophyta on physical characteristics such as current speed and sediment stability (Peterson et al., 1984) or modifications in biological interactions such as predation (Virnstein, 1977; Nelson, 1979; Heck \& Thoman, 1981; Flynn, 1993). Densities of macrobenthic organisms in a salt marsh system often fluctuate greatly with season (Tararam \& Wakabara, 1987; Lana \& Guiss, 1991; Flynn, 1993), the same is also true to plant biomass, which makes the study of salt marsh structures more difficult.

Over the Canancia intertidal marsh, densities of Spartina alterniflora plants appear in sparsely or densely arranged patches, both in tall and short forms. In this paper, we describe and compare the structure and seasonal variability of macrobenthic associations in such patches of a S. alterniflora bed at Arrozal Point.

\section{Material and methods}

Cananéia lagoon estuarine region is located in the southern coast of São Paulo state ( $\left.25^{\circ} 02^{\prime} \mathrm{S}-47^{\circ} 56^{\prime} \mathrm{W}\right)$. At Arrozal Point (Fig. 1), the marsh investigated presents average salinity values higher than $28 \%$, surface water temperature around $20^{\circ} \mathrm{C}$ in winter and $32^{\circ} \mathrm{C}$ in summer. Local tides are characterized by diurnal inequalities. A complete description and characterization of the system is given by Schaeffer-Novelli et al. (1990).

At this shore, there is one of the largest marshes in the region with patches of plants loosely aggregated (6 plants $/ 0.03 \mathrm{~m}^{2}$ ) comprising groups of scattered individuals, and others with plants densely aggregated (12 plants/0.03 $\mathrm{m}^{2}$ ). In both situations $S$. alterniflora can be found in both forms, tall $(100 \mathrm{~cm})$ and short $(40 \mathrm{~cm})$.

Four intertidal stations were established, comprising patches with tall and short $S$. altemiflora sparsely distributed (Pt1 and Pt2), and densely distributed (Pt3 and Pt4).

Faunal and environmental samples were taken once each season, in July 1988 (winter), October 1988 (spring), January 1989 (summer) and April 1989 (autumn). Surface water temperature was determined by a thermometer. Salinity was determined using a hand refractometer and dissolved oxygen was analyzed according to Strickland \& Parsons (1968). Sediment samples were analyzed for silt-clay percentage, mean grain size (Suguio, 1973) and organic matter by the $\mathrm{H}_{2} \mathrm{O}_{2}$ digestion method.

Faunal samples consisted of 3 replicates for each $S$. alterniflora patch (Pt1, Pt2, Pt 3 and Pt4) taken by a corer $20 \mathrm{~cm}$ in internal diameter penetrating the sediment to a depth of $10 \mathrm{~cm}$. Twelve samples were taken in each season. $S$. altemiflora leaves were clipped at ground level and searched for epifaunal organisms. Sediment samples were sieved through $1 \mathrm{~mm}$ and $0,5 \mathrm{~mm}$ meshes, fixed in $10 \%$ formalin and then preserved in $70 \%$ ethanol. All specimens were identified at the lowest practical taxonomic level and counted. S. alterniflora plants of each sample were dried for $24 \mathrm{~h}$ in a shady place and weighted in a normal scale. The number and size of plants per corer were counted and measured.

All species with at least 2 individuals per sample (Jackson, 1972) were included in a matrix of $\log (x+1)$ transformed data for subsequent quantitative analyses.

The structure of the macrobenthic associations was evaluated by the total number of individuals (n), species richness (s), diversity $\left(\mathrm{H}^{\prime}\right)$ and evenness $\left(\mathrm{J}^{\prime}\right)$. Species richness was evaluated by the total number of species per sampled patch. Shannon index $\left(H^{\prime}\right)$ was used for measuring diversity.

One-way analyses of variance (ANOVA) were used to test for differences in water parameters such as temperature, salinity and dissolved oxygen. Two-way analyses of variance with replication were used to determine differences in sediment (grain size, silt-clay and organic content), community (n, s, H', J') and plant parameters (aggregation level and size), taking into account habitat type and sampling season, as independent factors. A 5 per cent level of confidence was assumed.

Morisita index (Ono, 1961; Grassle \& Smith, 1976) and the WPGA (Weighted pair group average) method were used to cluster species (R-mode) and samples (Q-mode). Principal component analyses were employed in order to 


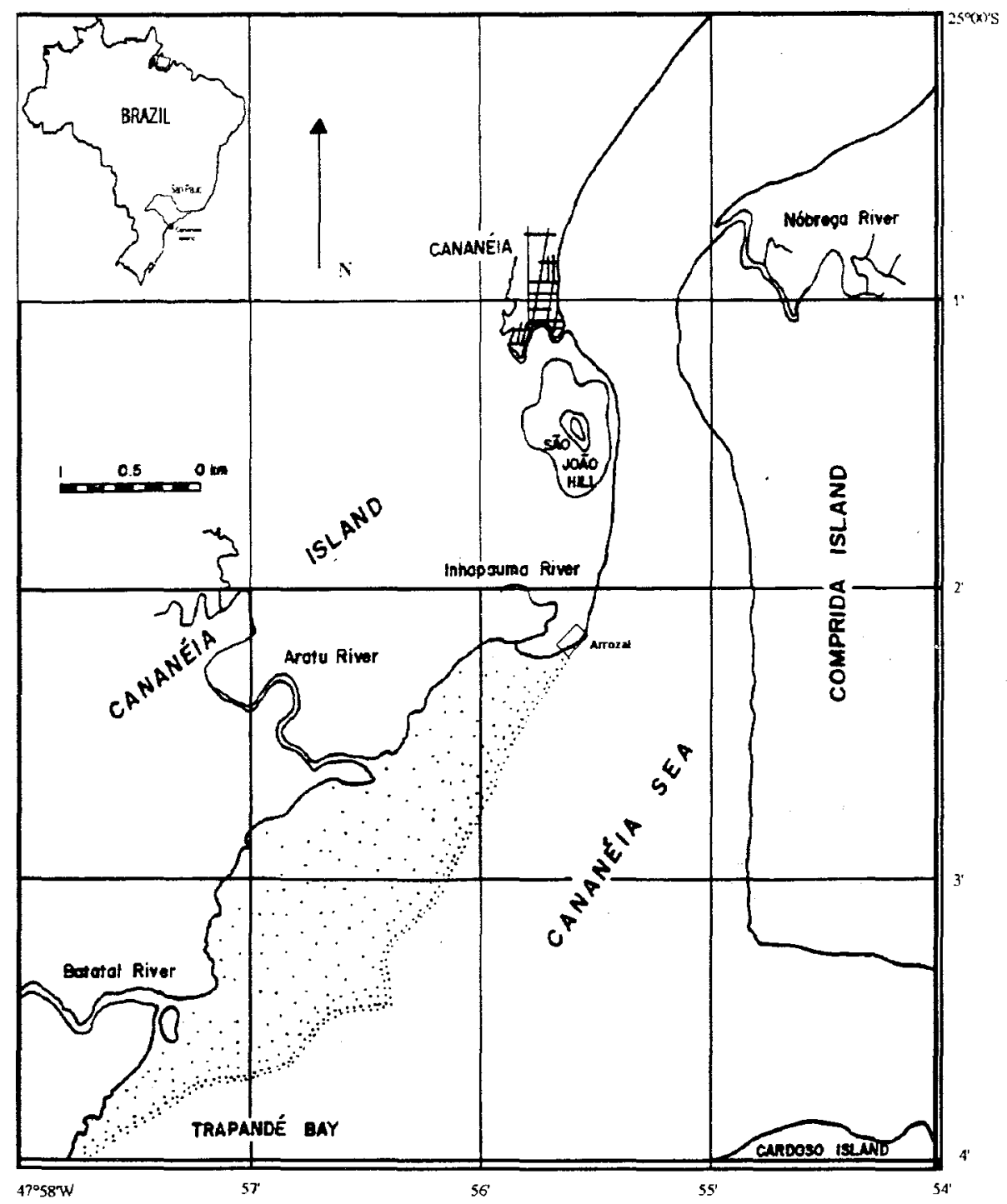

Fig. 1. Location of sampling site (Arrozal) in Cananéia Lagoon estuarine region, São Paulo State, southeastern Brazil.

reduce the multivariate nature of the data to a few interpretable dimensions.

\section{Results}

Temporal variations in temperature, salinity and dissolved oxygen of surface water are shown in Figure 2. Table 1 summarizes the variations of these parameters with
ANOVA results. These parameters reveal a significant temporal variation.

The temporal variations observed in the total biomass of S. altemiflora (leaves, rhizomes and roots) in each patch are shown in Figure 3. Table 2 summarizes the variation of these parameters with the results of two-way ANOVA, as observed, biomass values were statistically different both in patches and in seasons considered. Higher values were associated with dense $S$. alterniflora patches and autumn/winter periods. 


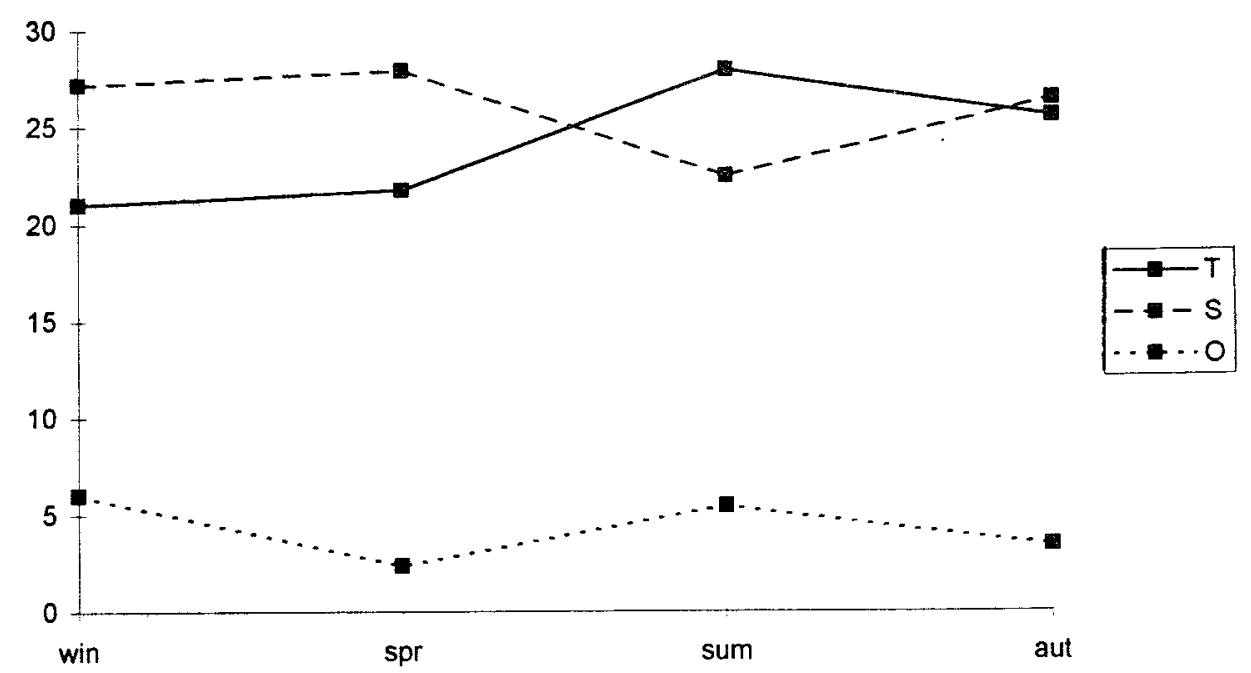

Fig. 2. Temporal variation in temperature $\left(T^{\circ} \mathrm{C}\right)$, salinity $(S \%)$ and dissolved oxygen $(\mathrm{ml} / \mathrm{l})$ of the superficial water.

Table 1. Variation range of superficial water variables and results of one-way ANOVA

Sediment parameters were statistically different when $\left(^{*}\right)=$ significant difference at $5 \%$ level of confidence

\begin{tabular}{|l|c|c|}
\hline \multicolumn{1}{|c|}{ Parameters } & variation range & p-value \\
\hline \hline Salinity $(\%$ ) & $22.4-28.1$ & ${ }^{\star} 3.19 \mathrm{E}-7$ \\
\hline Temperature $\left({ }^{\circ} \mathrm{C}\right)$ & $20-28$ & ${ }^{\star} 0,00012$ \\
\hline Dissolved Oxygen $(\mathrm{ml} / \mathrm{l})$ & $2.53-6.80$ & ${ }^{\star} 1.15 \mathrm{E}-07$ \\
\hline
\end{tabular}
different patches were considered, but were similar among sampling times (Table 2). Silt-clay porcentage and sediment organic content were found to have higher values at the dense $S$. altemiflora patches.

A total of 2,023 macrobenthic animals belonging to 31 species were considered, referring to the mean values of species abundance of the three replica of each different patch sample (Table 3). The infaunal polychaetes Capitella capitata, Isolda pulchella, Nereis oligohalina and Laeonereis acuta accounted for $44.0 \%$ of all individuals, while

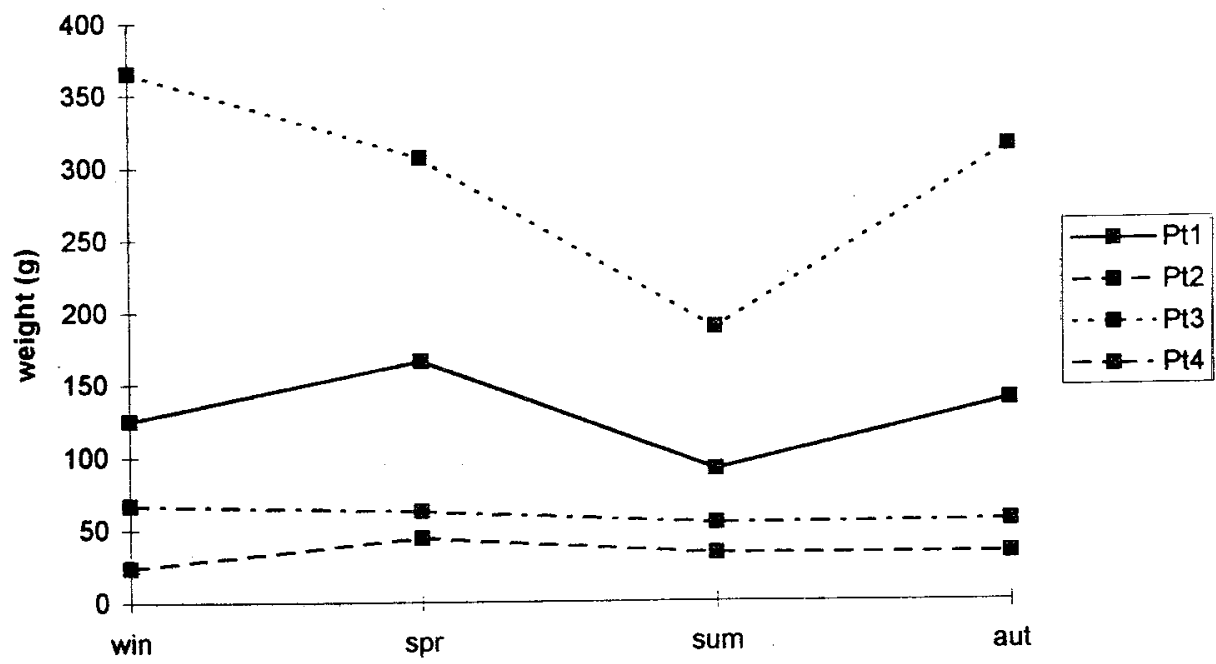

Fig. 3. Seasonal variation in biomass of Spartina for each sampling patch (Pt). 
Table 2. Variation range of variables and results of two-way ANOVA with replication evaluating effect of sediment parameters, fauna parameters and plant biomass $(*)=$ significant difference at $5 \%$ level of confidence

\begin{tabular}{|c|c|c|c|c|c|c|c|}
\hline \multirow[t]{2}{*}{ Parameters } & \multicolumn{3}{|c|}{ variation range } & \multirow[b]{2}{*}{ Pt4 } & \multicolumn{3}{|c|}{ p-value } \\
\hline & Pt1 & Pt2 & Pt3 & & etween sites | & time & interaction \\
\hline Mean grair & $2.95-3.08$ & $3.0-3.08$ & $3.06-3.33$ & $3.15-4.6$ & 0.295 & 0.129 & 0.551 \\
\hline Organic matter $(\%)$ & 0.0 .1 & $0-0.1$ & $0.5-0.9$ & $0.1-0.9$ & *2.14E-07 & 0.06 & 0.007 \\
\hline Silt-clay (\%) & $0.1-0.27$ & $0.03-0.22$ & $5.31-12.58$ & $5.4-13.58$ & $5.96 \mathrm{E}-07$ & 0.007 & 0.09 \\
\hline \multicolumn{8}{|l|}{ Fauna } \\
\hline number of species (s) & rom 2 to 16 & from 0 to 16 & from 6 to 14 & from 9 to 16 & *1.17E-15 & $7.29 \mathrm{E}-17$ & $7.29 E-15$ \\
\hline density (inds $10.03 \mathrm{~m}^{2}$ ) & $2-375$ & $0-206$ & $44-234$ & $36-310$ & $1.36 \mathrm{E}-10$ & $2.75 E-15$ & $2.25 \mathrm{E}-13$ \\
\hline diversity $\left(\mathrm{H}^{\prime}\right)$ & $0.693-1.5$ & $0.25-1.96$ & $1.02-2.157$ & $1.182-2.22$ & ${ }^{*} 6.87 \mathrm{E}-10$ & $* 4.43 \mathrm{E}-10$ & $6.90 E-06$ \\
\hline evenness $(\mathrm{J})$ & $0.5110-1$ & $0.142-0.84$ & $0.57-0.841$ & $0.461-0.862$ & $3.52 \mathrm{E}-08$ & 0.00105 & $6.94 \mathrm{E}-11$ \\
\hline Biomass of Spartina (g) & $71.5-182.0$ & $15.0-54.0$ & $188.0-450.0$ & $40.0-73.0$ & * $4.98 \mathrm{E}-20$ & ${ }^{*} 0.0025$ & 0.091 \\
\hline
\end{tabular}

epifaunal forms such as Heleobia australis, Littorina angulifera, Tholozodium rhombofrontalis and Sphaeromopsis mourei accounted for $39.5 \%$ of the total. The 13 numerically dominant species accounted for $92.5 \%$ of all individuals. The other 18 species were not included in quantitative analyses (Table 3 ).

Inverse analyses of data from sites in all seasons (Fig. 4) yiclded four group species: group a, the infaunal polychaetes $I$. pulchella, $N$. oligohalina and $C$. capitata; group b, the epifaunal amphipods Parhyale hawaiensis and Platorchestia sp; group c, the molluses $H$. australis, $L$. angulifera and $A$. brasiliensis; and group d, the epifaunal isopods $T$. rombofrontalis and $S$. mourei . Hydrobiidae and $S$. grubii were not grouped probably due to their discontinuous temporal occurrence. L. acuta was the only species more abundant in short S. alterniflora forms.

Classification analysis of sampling times indicated that groups in the same sample patch were formed primarily by spatial similarity and peak densitics of macrofauna and secondarily by temporal patterns. Three groups were identified at $60 \%$ similarity level (Fig. 5); the first one comprising samples from the four patches in cold periods, mainly winter; the second, samples collected from dense $S$. alterniflora (Pt3 , Pt4); the third, samples from sparsely distributed S. alterniflora (Pt1, Pt2).

Species or group of species showed a strong seasonal component (Fig. 6). In winter, polychaetes from group a ( $N$. oligohalina, I. pulchella and C. capitala) were the dominant species in tall S. alterniflora and L. acuta in sparsely distributed S. altemiflora. T. rhombofrontalis and S. mourei (group d), P. hawaiensis and Platorchestia sp (group b) were also abundant in winter. H. alsstralis, $L$. angulifera and A. brasiliensis (group c) appearcd with higher densities in sparse S. alterniflora (Pt1, P12). In spring, polychaetes (group a) were restricted to densely distributed $S$. altemiflora (Pt3 and Pt4). Mollusc spccies (group c) were abundant in all sampling patches. All species exhibited lower densities in summer. Isopod species (group d) dominated in short sparse $S$. alterniflora, while polychaete species (group a) remained restricted practically to dense $S$. alterniflora patches. In autumn, sparse patches of $S$. alterniflora were practically devoid of associated fauna, with molluscs of group c predominating in densely distributed patches, followed by $L$. acuta and polychaete species (group a).

Species richness differed statistically between habitats, with higher values in tall S. altermiflora patches (Fig. 7). Temporal differences were evident at the sampled patches, with higher number of species in colder months, winter and spring. Species diversity and evenness, although significantly different between sampling patches and time, did not show any distinct seasonal patterns. Although the rare species which greatly influenced the Shannon index were withdrawn, this information index was still greatly affected by the evenness component, disguising any spatial or seasonal pattern.

In terms of the faunal components associated to the $S$. alterniflora patches observed, it was noticed that in the tall sparse $S$. alterniflora patch (Pt1), group c species, $H$. australis, $L$. angulifera and $A$. brasiliensis were the most abundant; the first two are epifaunal grazers and the third species an infaunal suspension feeder, followed by the infaunal deposit feeders polychaete species (group a). Density peaks in tall sparse $S$. alterniflora patch occurred in winter/spring periods. In the short sparse $S$. altemiflora patch (Pt2), the dominant species were, T. rhombofrontalis and $S$. mourei, both grazers, followed by $L$. acuta. Density peak in the tall sparse $S$. alterniflora patch occurred in summer. In the tall dense $S$. alterniflora patch the dominant species were polichaetes of group a, followed by the mud mollusc Hidrobiidae. Density peak in this patch was in winter. In the short dense $S$. altemiflora patch the dominant 
Table 3. Density (inds. $/ 0.03 \mathrm{~m}^{2}$ ) of the species in each sampling location. () = species number used in quantitative analyses.

\begin{tabular}{|l|r|r|r|r|}
\hline \multicolumn{1}{|c|}{ Species } & Pt1 & Pt2 & $P 13$ & $P$ t4 \\
\hline \hline Acteocina canaliculata & 3 & 1 & 0 & 4 \\
\hline Bittium varium & 3 & 4 & 0 & 4 \\
\hline Costoanachis sp & 2 & 1 & 0 & 3 \\
\hline Epitonium sp & 0 & 1 & 0 & 1 \\
\hline Heleobia australis (1) & 153 & 40 & 37 & 260 \\
\hline Littorina angulifera (2) & 25 & 5 & 13 & 14 \\
\hline Nassarius sp & 3 & 3 & 2 & 7 \\
\hline Neritina virginia & 7 & 0 & 3 & 6 \\
\hline Turbonilla sp & 2 & 1 & 0 & 2 \\
\hline Odostomia sp & 2 & 0 & 8 & 1 \\
\hline Hydrobiidae (13) & 0 & 0 & 45 & 2 \\
\hline Anomalocardia brasiliensis (3) & 15 & 7 & 7 & 21 \\
\hline Mytella guyanensis & 3 & 2 & 9 & 1 \\
\hline Sphenia antillensis & 1 & 1 & 4 & 5 \\
\hline Capitella capitata (4) & 253 & 3 & 191 & 68 \\
\hline Isolda pulchella (5) & 7 & 1 & 39 & 19 \\
\hline Laeonereis acuta (6) & 15 & 39 & 12 & 59 \\
\hline Lumbrineris hebes & 0 & 0 & 0 & 7 \\
\hline Neanthes succinea & 1 & 2 & 2 & 3 \\
\hline Nereis oligohalina (7) & 43 & 3 & 53 & 51 \\
\hline Perinereis ponteni & 1 & 0 & 5 & 0 \\
\hline Perinereis yancaurica & 3 & 0 & 8 & 0 \\
\hline Sigambra grubii (8) & 0 & 0 & 14 & 1 \\
\hline Cassidinidea tuberculata & 1 & 0 & 5 & 4 \\
\hline Dies fuminensis & 1 & 1 & 2 & 0 \\
\hline Tholozodium mombofrontalis (10) & 24 & 132 & 2 & 15 \\
\hline Sphaeromopsis mourei (11) & 3 & 72 & 9 & 14 \\
\hline Parhyale hawaiensis (9) & 8 & 0 & 19 & 3 \\
\hline Platorchestia sp (12) & 12 & 7 & 21 & 4 \\
\hline Hyale media & 1 & 1 & 2 & 2 \\
\hline Zeuxo sp & 0 & 0 & 11 & 0 \\
\hline \hline Total & 592 & 327 & 523 & 581 \\
\hline & & 2023 & & \\
\hline
\end{tabular}

species were molluscs of group c, followed by L. acuta and group a species. Density peak in this patch occurred in spring (Fig. 6 ).

Sample and parameter points of principal components analyses were projected simultancously in the factorial space (Fig. $8 \mathrm{a}$ and b). There was a broad match with the pattern of responses exhibited by cluster analysis. The first component accounted for $36.6 \%$ of the total variance. Species of infaunal polychaetes (group a), epifaunal amphipods (group b), molluscs (group c) and $S$. grubii, with positive coordinates, werc opposed to isopod species (group d) and $L$. acuta with negative coordinates. The first species were related to higher $S$. alterniflora biomass. The first axis also distinguished locations with dense $S$. altemiflora from locations with sparsely distributed $S$. alterniflora. Physical-chemical parameters, such as silt-clay percentage and organic matter, besides form growth and biomass plant, showed positive coordinates. Species and site positions on the first axis can be regarded as a response to the aggregation level of $S$. alterniflora. The second component (20.7\% of data variance) separated species with higher densities from those with lower densities. Besides, this axis also separated tall $S$. alterniflora patches from short $S$. alterniflora patches. The third component (11.9\% of data variance) separated infaunal species, with negative coordinates related with the rhizome and roots, from epifaunal species. Interpretation of the fourth component was not clear.

\section{Discussion}

The results suggest that differences in form and aggregation of $S$. altemiflora plants impart changes in the structure of macrobenthic fauna associated to this vegetation. There was a similar composition of species among marsh locations with marked differences in the relative abundance of the dominant components. Each 


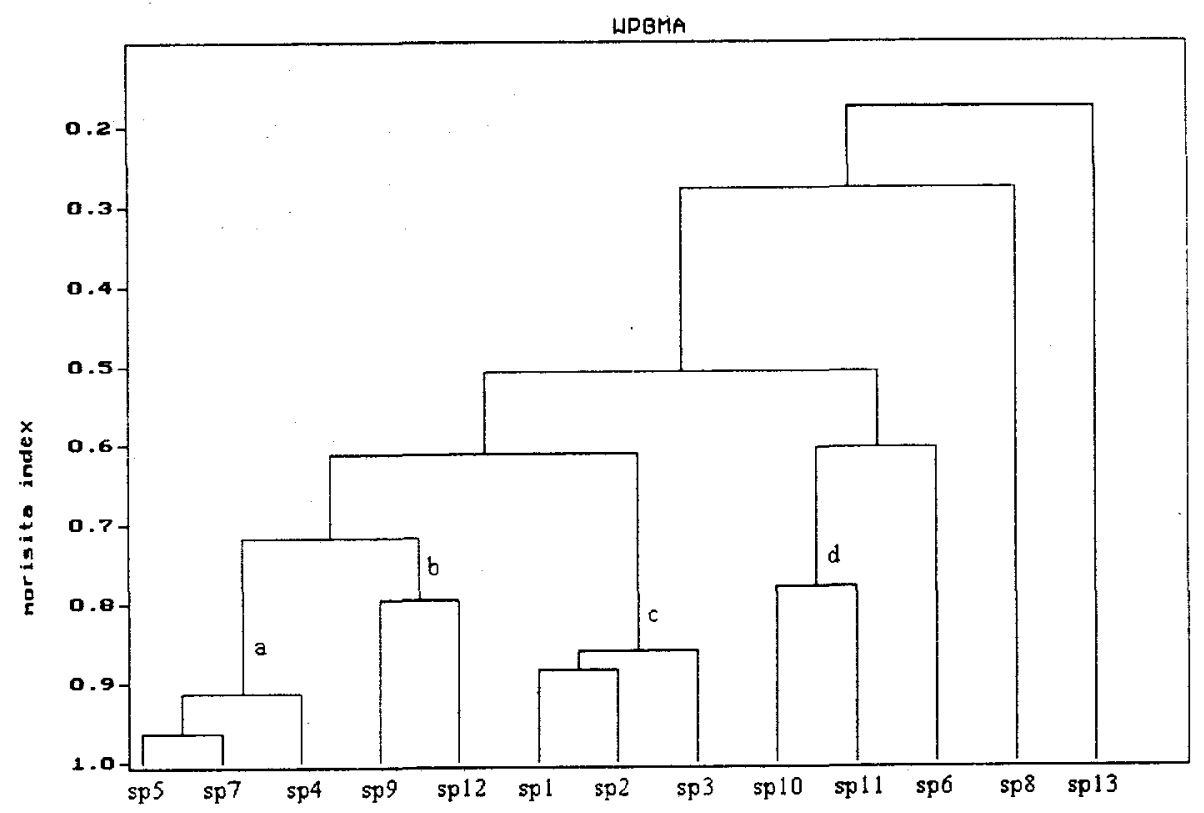

Fig. 4. Dendogram of species. Species groups a $(\mathrm{sp} 4=$ Capitella capitata, sp5 = Isolda pulchella, $\mathrm{sp} 7=$ Nereis oligohalina $) ; \mathrm{b}(\mathrm{sp9}=$ Parhyale hawaiensis, $\mathrm{sp12}=$ Platorchestia $\mathrm{sp})$; $\mathrm{c}$ (sp1 = Heleobia australis, $\mathrm{sp2}=$ Littorina angulifera, $\mathrm{sp} 3=$ Anomalocardia brasiliensis); $\mathrm{d}$ (sp10 $=$ Tholozodium nombofrontalis, sp11 = Sphaeromopsis mourei) and others (sp6 = Laeonereis acuta, $\mathrm{sp8}=$ Sigambra grubii and $\mathrm{sp13}=$ Hydrobiidae $)$ indicated.

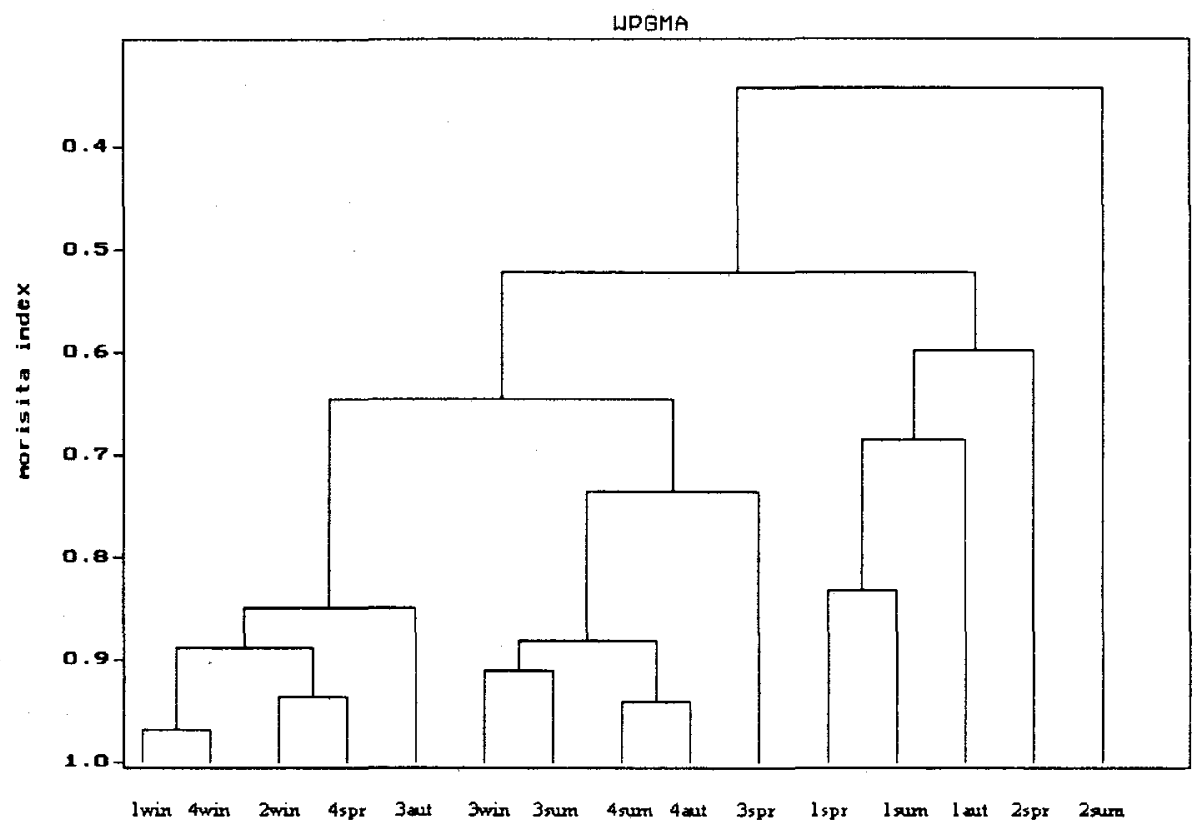

Fig. 5. Dendogram of sampling seasons at four different patches $(P t): 1-4$. (win $=$ winter, spr $=$ spring, sum $=$ summer, aut $=$ autumn). 
Winter

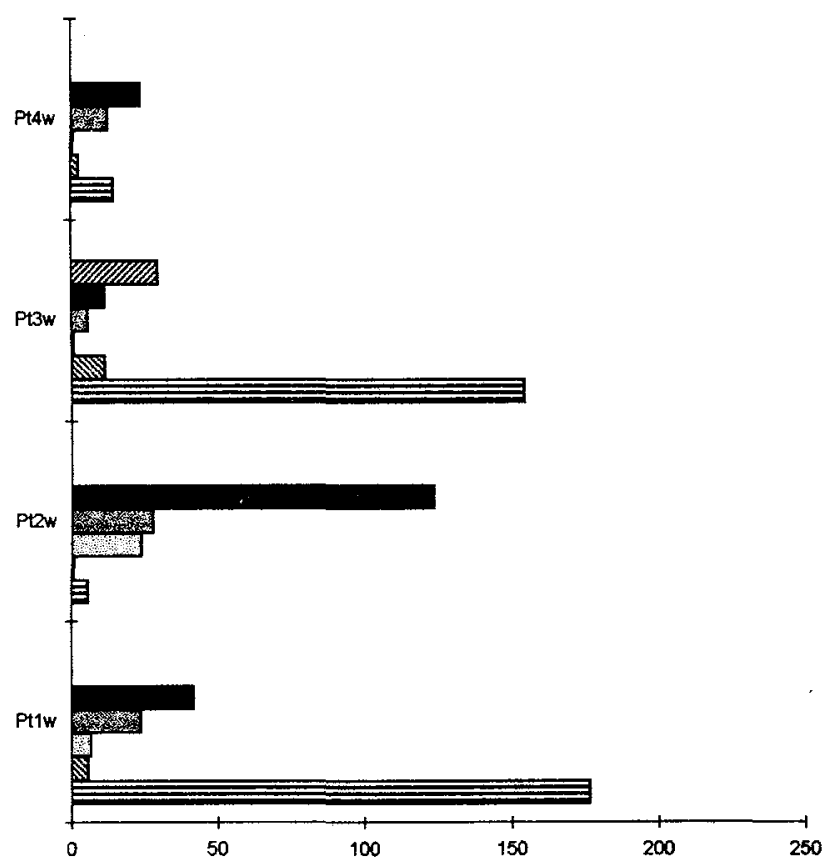

Summer

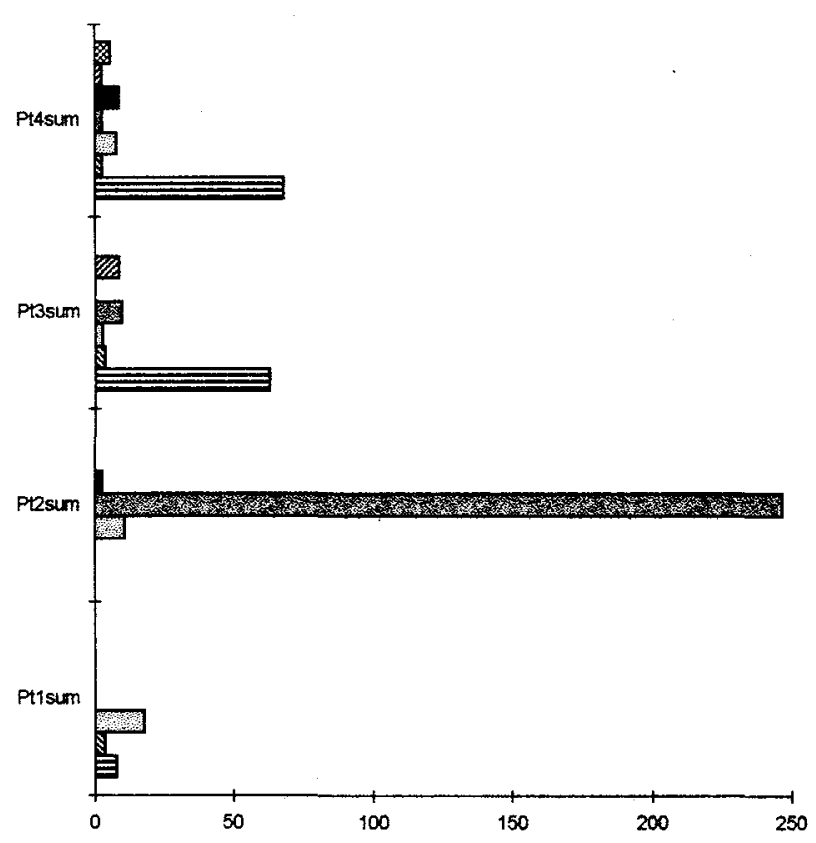

Spring

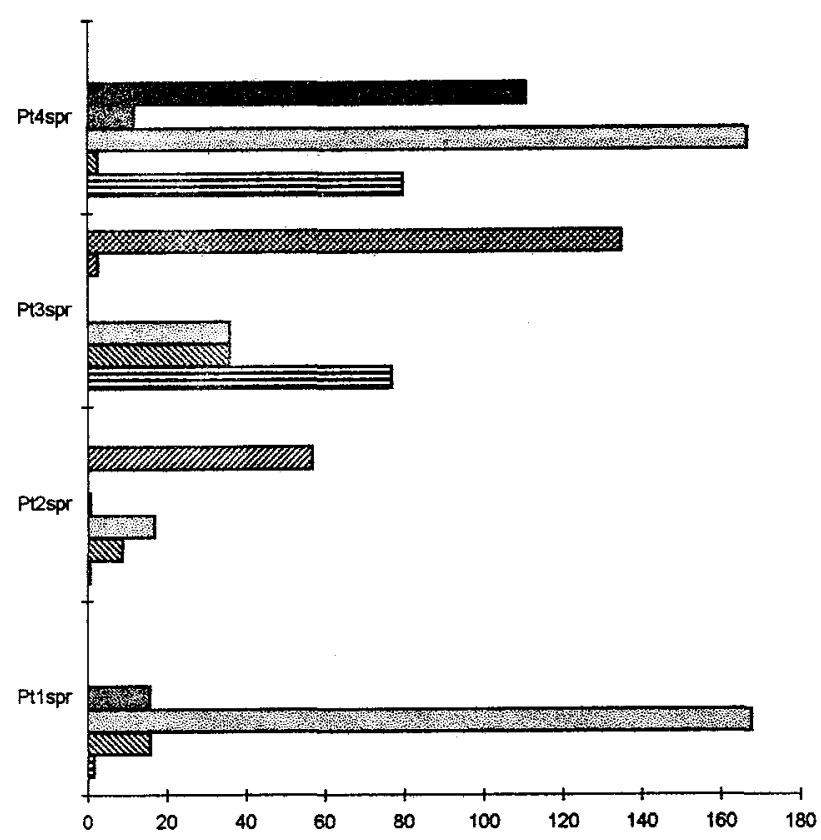

Autumn

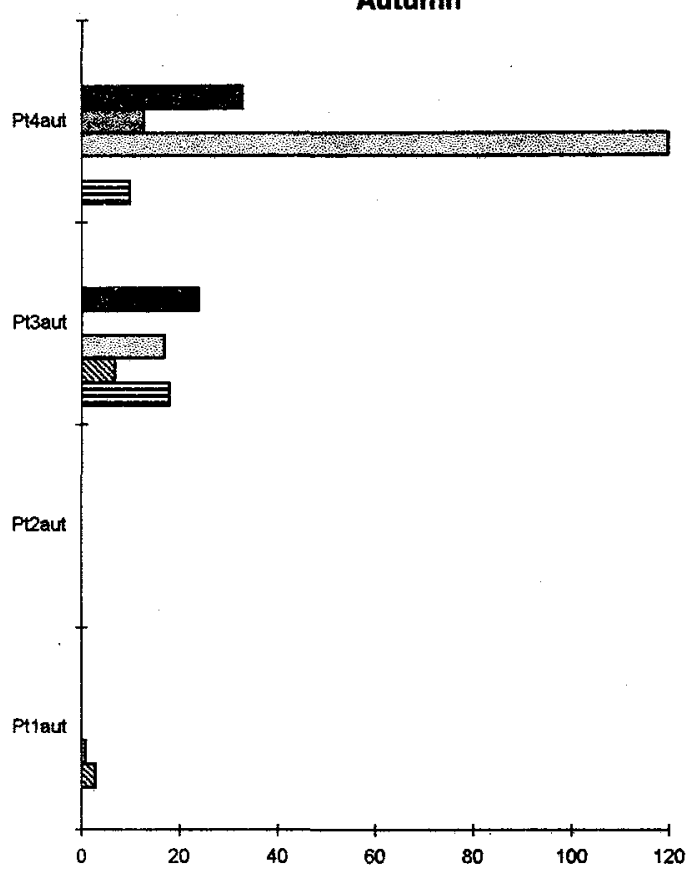

$\begin{array}{llll}\text { 目GrA } & \text { GrB } & \text { 圆 GrC } \\ \text { sp06 } & \text { sp08 } & \text { 图sp13 }\end{array}$

Fig. 6. Distribution and density of species or groups of species per $0.03 \mathrm{~m}^{2}$ at each patch. (GrA-D = species of groups A-D, sp06 = Laeonereis acuta, sp08 = Sigambra grubii, $\operatorname{sp13}=$ Hydrobiidae). 

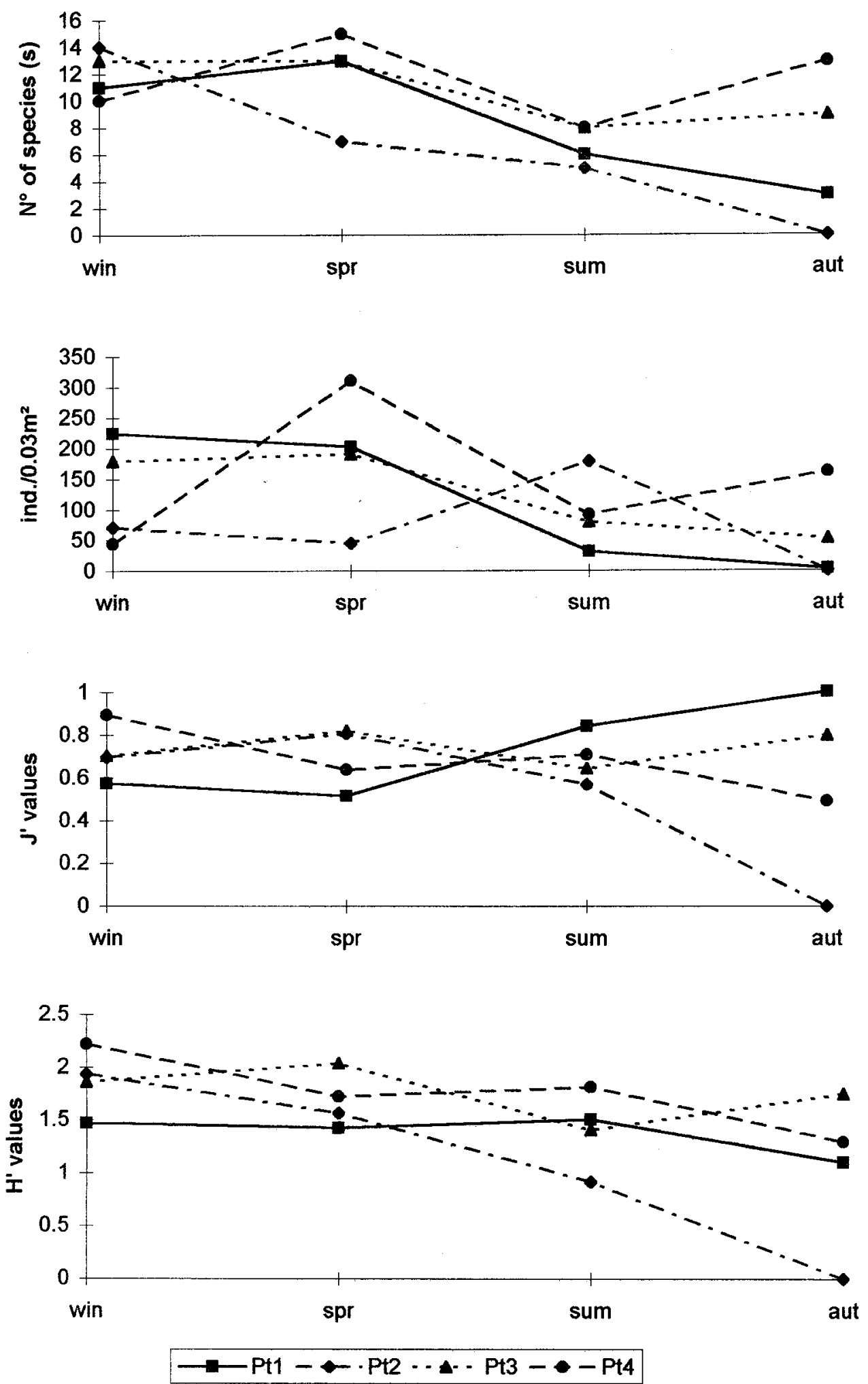

Fig. 7. Temporal variation in number of species $(s)$, diversity $\left(H^{\prime}\right)$, evenness $\left(J^{\prime}\right)$ and mean density per $0.03 \mathrm{~m}^{2}$ of benthic macrofauna at each sampling patch $(\mathrm{Pt})$. 


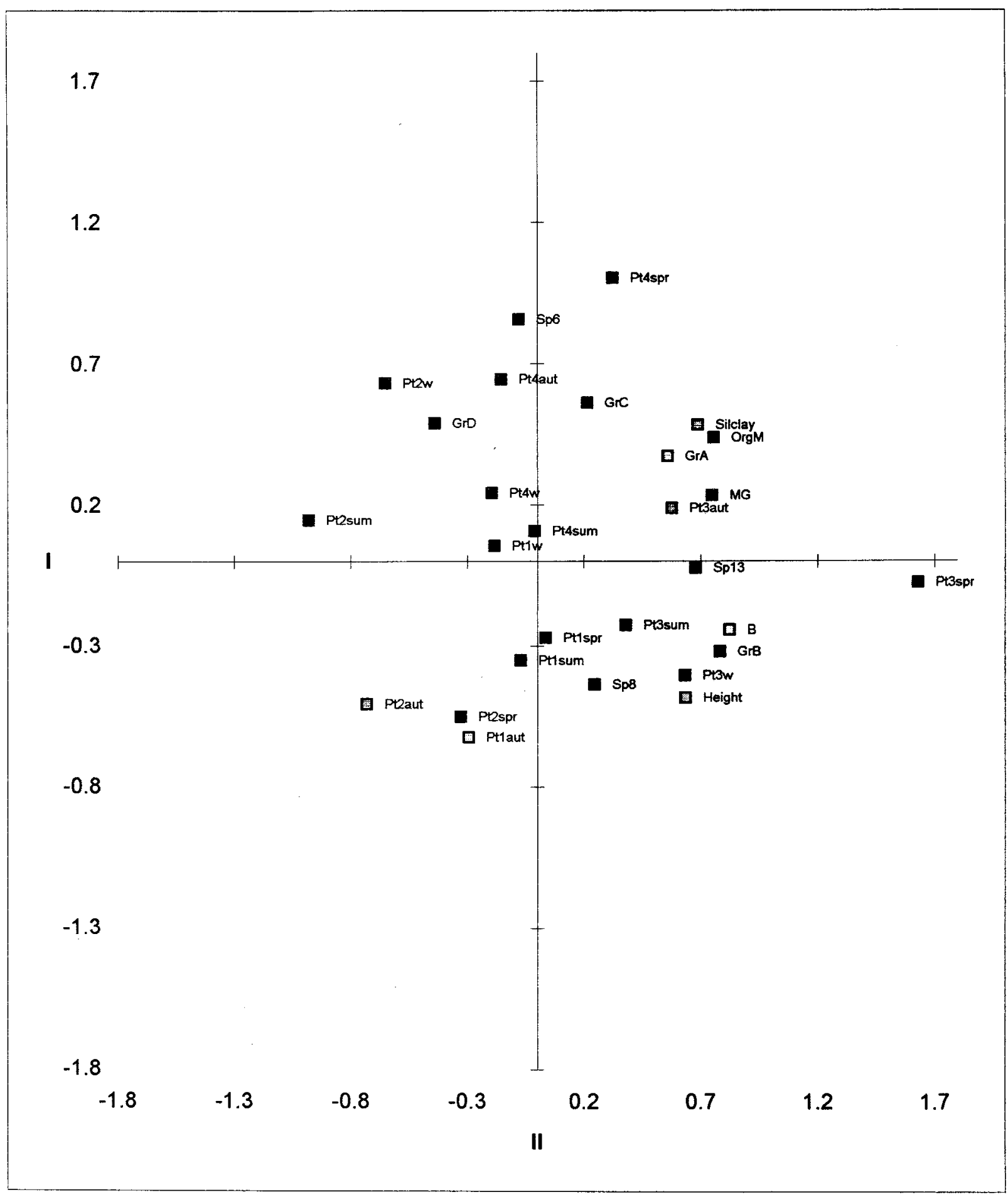

Fig. 8a. Principal components analysis of species, sampling seasons and physico-chemical parameters at each sampling station. Axes I and II. ( $w=$ winter, sum = summer; aut = autumn; spr = spring; $\mathrm{Pt}=$ patch; $\mathrm{Gr}=$ groups; Silclay $=\%$ silt-clay; $\operatorname{Org} M=$ organic matter; $M G=$ mean grain size). 


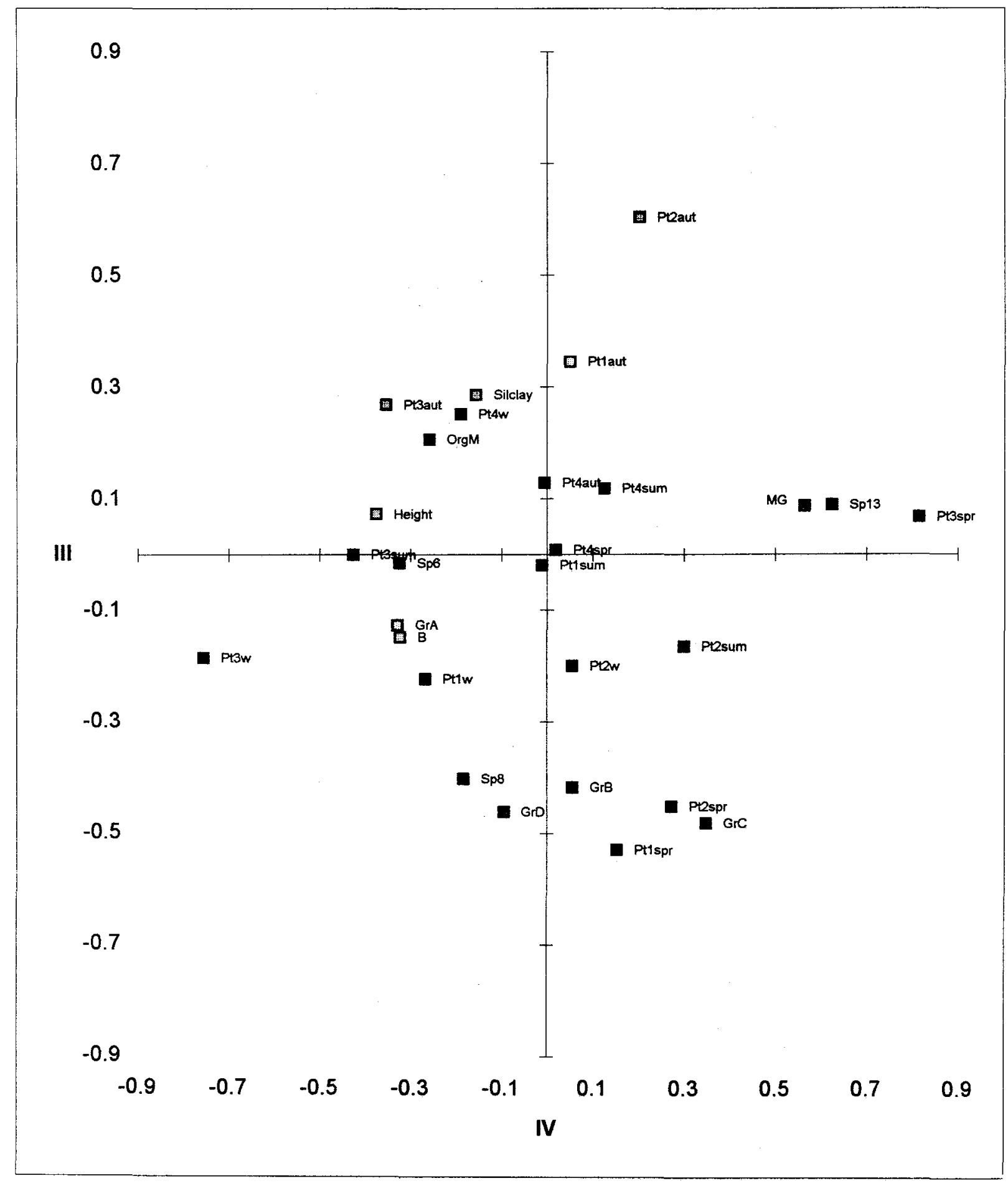

Fig. 8b. Principal components analysis of species, sampling seasons and physico-chemical parameters at each sampling station. Axes III and IV. ( $w=$ winter, sum = summer; aut = autumn; spr = spring; $\mathrm{Pt}=$ patch; $\mathrm{Gr}=$ groups; Silclay $=\%$ silt-clay; $\operatorname{Org} M=$ organic matter; $M G=$ mean grain size). 
sampled patch displayed an alternation of dominance among the few numerically expressive species. Schneider \& Mann (1991) attributed this heterogeneous response to vegetation type to the biology of individual species, with respect to suitability of macrophytes as food resource and living space. Bell \& Westoby (1986) pointed out that community measures as well as total abundance of individuals are unreliable variables for testing the effects of height and densities of plants since component species can give opposite responses. These authors showed that preference for a particular plant was highly species-specific, indicating that no vegetation characteristic made it a suitable substratum for all animals.

Small-scaled aggregation of infaunal organisms exists in association with salt marsh vegetation (Rader, 1984; Lana \& Guiss, 1991; Flynn, 1993). In the present study the infaunal polychaetes $N$. oligohalina, $I$. pulchella and $C$. capitata preferred patches with higher vegetal biomass deriving mainly from $S$. alterniflora level of aggregation. Epifaunal amphipods grazers as .P. hawaiensis and Platorchestia sp, in the other hand, were related to plant height, numerically more abundant between tall forms of $S$. altemiflora. This finding is in accordance with Stoner's (1980) conclusions that epifaunal amphipods select the vegetation on the basis of blade surface area.

The heterogeneous patterns of temporal variation were strongly influenced by the populational dynamics of the dominant species. The abundance and species richness of tall S. altemiflora associations showed a pattern already documented by Flynn (1993) with high densities at cold months, followed by a sharp decline in summer and autumn. Associations related to short $S$. altemiflora forms presented peak densities in summer, when in sparsely distributed S. alterniflora patches, or in spring, when in dense $S$. altemiflora patches. These peaks reflect the populational fluctuations of the groups of dominant species, respectively, epifaunal isopods and molluscs.

Mobile organisms densities associated to salt marsh $S$. alterniflora greatly fluctuate with season (Tararam \& Wakabara, 1987; Lana \& Guiss, 1991; Flynn, 1993). Rapid population increases are explained in terms of the settlement of planktonic larvae and rapid growth rates of brooding invertebrates (Edgar \& Moore, 1986). But the factors responsible for the marked populational decline are not well understood. Normally this decline is explained by an increase in predatory activities, but in Cananéia macropredators activity does not justify the population decline (Flynn, 1993), since both, the cage experiment and control experienced this abrupt decline. Heck \& Thoman (1981) and Edgar (1990), among others, concluded that their findings were not consistent with the hypothesis of macropredators controlling the fauna. So, it seems that exploitative competition has to be fully investigated. Because the vaste majority of macrobenthic species are generalist feeders which can utilize a variety of detrital, plant and animal material, diffuse exploitative competition can therefore be widespread amongst the macrobenthos, contrasting with the widely held view that the role of competition in structuring macrobenthic communities is minor, especially in comparison with the role of predation.

As Reice \& Stiven (1983) suggested, our results also seem to stress that the initial idea of homogeneity created by a monoculture of $S$. altemiflora masks the reality of a truly patchy ecosystem. The presence of $S$. altemiflora in different aggregation levels and growth forms, coupled with seasonal changes of species probably related to detritus availability, play an importante role on the abundance and maintainance of a macrofaunal association. Sediment parameters seem to exert a secondary influence. Further investigations on the feeding strategies of the associated fauna should be carried out to evaluate the effects of food competition in the organization of these communities.

\section{Acknowledgements}

This study was made possible through post-doc grant provided by CNPq (Conselho Nacional de Desenvolvimento Científico e Tecnológico) - Proc. 300.417.194-2 to the senior author. Sonia Maria Araújo Barreto provided invaluable assistance during the sampling and sorting of biological material.

\section{References}

Bell, J. D. \& Westoby, M. 1986. Importance of local changes in leaf height and density to fish and decapods associated with seagrasses. J. expl mar. Biol. Ecol., 104:249-274.

Edgar, G. J. 1990. The influence of plant structure on the species richness, biomass and secondary production of macrofaunal assemblages associated with Western Australian seagrass beds. J. expl mar. Biol. Ecol., 137:215-240.

Edgar, G. J. \& Moore, P. G. 1986. Macro-algae as habitat for motile macrofauna. Monogr. biol., 4:255-277. 
Flynn, M. N. 1993. Aspectos ecológicos das associações de espécies e avaliação do efeito da predação sobre a estrutura da macrofauna bentônica de bancos de Spartina (Canancia, SP, Brasil). Tesc de doutorado. Universidade de São Paulo, Instituto Oceanográfico. $84 \mathrm{p}$.

Grassle, J. F. \& Smith, W. 1976. A similarity measure sensitive to the contribution of rare species and its use in investigation of variations in marine benthic communities. Oecologia, 25:13-22.

Gunnil, F. C. 1983. Seasonal variations in the invertcbrate fauna of Pelvetia fastigiata (Fucaceae): cffects of plant size and distribution. Mar. Biol., 73:115-130.

Heck Jr, K. L. \& Thoman, T. A. 1981. Experiments on predatory-prey interaction in vegetated aquatic habitats. J. expl mar. Biol. Ecol., 53:125-134.

Jackson, J. B. C. 1972. The ecology of the molluses of Thalassia communities, Jamaica, West Indians. II. Molluscan population variability along an environment stress gradient. Mar. Biol., 14(4):304-337.

Lana, P. C. \& Guiss, C. 1991. Influence of Spantina altemiflora on the structure and temporal variability of macrobenthic associations in a tidal flat of Paranaguá Bay (Southeastern Brazil). Mar. Ecol.-Prog. Ser., 73:231-244.

Lewis, F. G. 1984. Distribution of macrobenthic crustaceans associated with Thalassia, Halodule and bare sand substrata. Mar. Ecol.-Prog. Ser.,18:101-113.

Lewis, F. G. \& Stoner, A. W. 1983. Distribution of macrofauna within seagrass beds: an explanation for patterns of abundance. Bull. mar. Sci., 33:296-304.

Nelson, W. S. 1979. Experimental studies of selective predation on amphipods. Consequences for amphipod distribution and abundance. J. expl mar. Biol. Ecol., 38:225-245.

Ono, Y. 1961. An ecological study of brachyuran community on Tomioka Bay, Amakusa. K. Y. Usher. Rec. oceanogr. Wks Japan, 5:199-210.

Orth, R.J.; Heck Jr, K. L. \& Weinstein, M.P. 1984. Faunal relationships in seagrass and marsh ecosystems. Estuaries, 7:273-274.
Peterson, C. H.; Summerson, H. C. \& Duncan P. B. 1984. The influence of seagrass cover on population structure and individual growth rate of a suspension-feeding bivalve, Mercenaria mercenaria. J. mar. Res., 42:123-138.

Rader, D. N. 1984. Salt-marsh benthic invertebrates: small-scale patterns of distribution and abundance. Estuaries, 7:123-138.

Reice, S. R. \& Stiven, A. E. 1983. Environmental patchiness, litter decomposition and associated faunal patterns in Spartina altemiflora marsh. Estuar. coast. Shelf Sci., 16:559-571.

Schaeffer-Novelli, Y.; Mesquita, H. S. L. \& Cintron-Molcro, B. 1990. The Cananéia lagoon estuarine system, São Paulo, Brazil. Estuaries, 13(2):193-203.

Schncider, F. I. \& Mann, K. H. 1991. Species specific relationship of invertebrates to vegetation in a scagrass bed. I. Correlational studies. J. expl mar.Biol. Ecol., 145:101-117.

Stoner, A. W. 1980. The role of seagrass biomass in the organization of benthic macrofaunal assemblages. Bull. mar. Sci., 30:537-551.

Strickland, J. D. \& Parsons, T. R. 1968. A practical handbook of seawater analysis. J. Fish. Res. Bd Can., 197:1-311.

Suguio, K. 1973. Introdução a sedimentologia. São Paulo, Edgard Blücher/EDUSP. 312 p.

Tararam, A. S. \& Wakabara, Y. 1987. Benthic fauna living on Spartina altemiflora of Cananeia estuarine

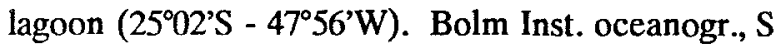
Paulo, 35(2):103-113.

Virnstein, R. W. 1977. The importance of predation by crabs and fishes on benthic infauna in Chesapeake Bay. Ecology, 58:1199- 1217.

Virnstein, R. W. \& Howard, R. K. 1987. The motile epifauna of marine macrophytes in the Indian River lagoon, Florida. II . Comparisons between drift algae and three species of seagrass. Bull. mar. Sci., 41:13-26.

(Manuscript received 24 November 1995; revised 20 Marsh 1996; accepted 23 April 1996) 